\title{
Darbepoetin, effective treatment of anaemia in paediatric patients with chronic renal failure
}

\author{
Jean-Luc André • Georges Deschênes • \\ Bernard Boudailliez • Françoise Broux • \\ Michel Fischbach • Marie-France Gagnadoux • \\ Benjamin Horen • Annie Lahoche-Manucci • \\ Marie-Alice Macher • Bernard Roussel • \\ Michel Tsimaratos $\cdot$ Chantal Loirat
}

Received: 17 July 2006 / Revised: 19 November 2006 / Accepted: 21 November 2006 / Published online: 11 January 2007

(C) IPNA 2007

\begin{abstract}
Darbepoetin alfa (DA) is a unique long-acting treatment for anaemia in patients with chronic renal failure (CRF). This study assessed the mean dose of DA to achieve and maintain haemoglobin $(\mathrm{Hb})$ levels between $11 \mathrm{~g} / \mathrm{dl}$ and $13 \mathrm{~g} / \mathrm{dl}$ in CRF children aged 11 years to 18 years. This
\end{abstract}

A prospective observational study, on behalf of the French Society for Pediatric Nephrology.

Preliminary results of this study were published in part as an abstract and presented as a poster at the European Society of Pediatric

Nephrology in Istanbul 11-13 September 2005 and at the ASN Renal Week in Philadelphia (Pennsylvania) 8-13 November 2005.

\section{J.-L. André $(\bowtie)$}

Pediatric Nephrology Unit, Hôpital d'Enfants, CHU de Nancy,

Rue du Morvan,

54511 Vandoeuvre les Nancy, France

e-mail: jl.andre@chu-nancy.fr

G. Deschênes

Pediatric Nephrology Unit, Assistance Publique-Hôpitaux

de Paris, Hôpital Trousseau,

75012 Paris, France

B. Boudailliez

Pediatric 1, Hôpital Nord, CHU,

80030 Amiens, France

F. Broux

Pediatric Nephrology Unit-CHU, Hopital Charles Nicolle,

76031 Rouen, France

M. Fischbach

Pediatric 1, Hopital de Hautepierre-CHU,

67098 Strasbourg, France

M.-F. Gagnadoux

Pediatric Nephrology Unit,

Assistance Publique-Hôpitaux de Paris,

Hôpital Necker-Enfants Malades,

75743 Paris, France observational, prospective study was conducted in 39 patients treated with DA. Twenty-nine patients were switched from recombinant human erythropoietin (r-HuEPO), and ten patients were naive to $\mathrm{r}$-HuEPO. Naive patients received initial doses of $0.45 \mu \mathrm{g} / \mathrm{kg}$ of DA. Switched patients received a dose adjusted to the prior dose of r-HuEPO (200 IU r-HuEPO:1 $\mu \mathrm{g}$ DA). Among the switched patients, 79.3\% received dialysis. No naive patients underwent dialysis. Overall, $74 \%$ of patients showed increased $\mathrm{Hb}$ level, with a mean value of $11.6 \pm 1.6 \mathrm{~g} / \mathrm{dl}$, using a mean DA dose of $0.63 \pm 0.48 \mu \mathrm{g} / \mathrm{kg}$ per week, and $66.7 \%$ patients reached the

\section{B. Horen}

Pediatric Nephrology Unit,

Hópital des Enfants-CHU,

31026 Toulouse, France

A. Lahoche-Manucci

Pediatric Nephrology Unit,

Hópital Jeanne de Flandre-CHU,

59037 Lille, France

M.-A. Macher · C. Loirat

Pediatric Nephrology Unit,

Assistance Publique-Hôpitaux de Paris,

Hôpital Robert Debré,

75019 Paris, France

B. Roussel

Pediatric Nephrology Unit,

American Memorial Hospital-CHU,

51092 Reims, France

M. Tsimaratos

Pediatric Nephrology Unit,

Assistance Publique-Hôpitaux de Marseille,

Hôpital de la Timone-Enfants,

Marseille, France 
target $\mathrm{Hb}$ level. $\mathrm{Hb}$ increased in naive patients from 9.5 (95\% CI: $7.7,11.4)$ to $11.7(95 \% \mathrm{CI}: 10.9,12.6) \mathrm{g} / \mathrm{dl}$ and in switched patients from 11.1 (95\% CI: $10.6,11.5)$ to 11.5 $(95 \%$ CI: $10.8,12.2) \mathrm{g} / \mathrm{dl})$. Higher doses of DA were needed in the "switched" than in the "naive" patients to maintain $\mathrm{Hb}$ levels over $11 \mathrm{~g} / \mathrm{dl}$, respectively 0.73 (95\% CI: $0.54,0.92)$ and 0.34 (95\% CI: $0.16,0.52) \mu \mathrm{g} / \mathrm{kg}$ per week. Our results indicate the doses of DA necessary to treat CRF patients aged 11 years to 18 years. DA was an effective treatment to stabilise CRF patients at extended dosing intervals.

Keywords Darbepoetin alfa · Paediatrics · Chronic kidney disease $\cdot$ Anaemia $\cdot r$-HuEPO $\cdot$ Dialysis $\cdot$ Haemoglobin . Chronic renal failure

\section{Introduction}

The dysfunction of erythropoietin (EPO) production because of declining renal function is the major cause of anaemia in patients with chronic renal failure. Therefore, dialysis patients with anaemia have an increased risk for cardiovascular morbidity and mortality [1]. Correction of anaemia through erythropoiesis stimulation leads to decreased blood transfusion requirements and anti-HLA immunisation [2], increased appetite and tolerance to exercise [3, 4] and improved school performance or quality of life $[5,6]$. Recombinant human erythropoietin (r-HuEPO) has become the standard of care in treating anaemia associated with chronic renal failure (CRF) in adults [7-9] as well as in children $[10,11]$. Conventional $r-H u E P O$ requires two to three subcutaneous or intravenous injections per week over long periods of time, until successful kidney transplantation restores kidney function. By contrast, darbepoetin alpha (DA) that has an increased sialic acid carbohydrate content promotes decreased clearance and has a longer serum halflife than $\mathrm{r}-\mathrm{HuEPO}$ [12-14], allowing a single weekly administration. Previous studies showed a similar potent effect of darbepoetin in adult as well as in paediatric patients either in pre-dialysis chronic renal failure or in end stage renal failure $[8,14-19]$. The present study aims to determine the mean dose of darbepoetin necessary to achieve and maintain haemoglobin levels between $11.0 \mathrm{~g} / \mathrm{dl}$ and $13.0 \mathrm{~g} / \mathrm{dl}$ in CRF patients aged from 11 years to 18 years.

\section{Subjects and methods}

\section{Patients}

This study was composed of 54 children aged between 11 years and 18 years with CRF, in stable condition, either needing dialysis (haemodialysis or peritoneal dialysis) or not, either pretreated or not with $\mathrm{r}$-HuEPO and having transferrin saturation (T-sat) $\geq 20 \%$. and/or serum ferritin $\geq 50 \mu \mathrm{g} / 1$ [the Kidney Disease Outcomes Quality Initiative (KDOQI) had not yet been published at the protocol onset, but results were analysed according to serum ferritin concentrations greater or less than $100 \mu \mathrm{g} / \mathrm{l}]$. The patients were classified as "switched" patients (previously treated by $\mathrm{r}$-HuEPO), or "naive" (never treated with $\mathrm{r}$-HuEPO). Written informed consent was obtained from all patients and/or their parents.

Patients with uncontrolled hypertension, cardiac failure, malignancy and/or haematological disease, known resistance to $\mathrm{r}$-HuEPO, or recent (within 3 months) kidney transplantation were excluded.

Methodology

The study was observational and prospective. Data for each patient were obtained monthly for 6 months. Once included, the patients received a dosage of darbepoetin (Aranesp ${ }^{\circledR}$ ) according to their previous treatment status and as recommended in the summary of product characteristics "Naive" patients received darbepoetin at initial doses of approximately $0.45 \mu \mathrm{g} / \mathrm{kg}$ once a week. However, as darbepoetin is supplied in pre-filled syringes containing from $10 \mu \mathrm{g}$ to $60 \mu \mathrm{g}$ (by steps of $10 \mu \mathrm{g}$ ), some patients received slightly lower or higher adjusted doses than $0.45 \mu \mathrm{g} / \mathrm{kg}$, because dose accuracy cannot be guaranteed if the syringe is partially injected. In fact, doses were pulled out to the upper range in a majority of patients. The real dose received by each patient was recorded (Table 2).

For "switched" patients, the initial dose of darbepoetin was calculated from the prior dose of r-HuEPO according to the following conversion index: $1 \mu \mathrm{g}$ darbepoetin for $200 \mathrm{IU}$ r-HuEPO. Patients receiving r-HuEPO two to three times weekly were switched to once-weekly darbepoetin, while those receiving weekly r-HuEPO were switched to every-other-week darbepoetin.

Statistical analysis

The population analysis considered all patients receiving the treatment and with $\mathrm{Hb}$ concentration evaluated at month 6 (M6). Those patients receiving a transplant during the study were not included in the analysis. Summary statistics (mean, median, SD, and number and percentage of subjects in each group for categorical variables) are presented for baseline and M6. Changes in $\mathrm{Hb}$ and darbepoetin dose comparing the baseline to M6 are summarised, with means, SD and two-sided $95 \%$ confidence intervals $(95 \% \mathrm{CI})$.

Fisher's exact test was used to compare the categorical variables, such as gender, dialysis, ferritin and T-sat between the study groups. Continuous data such as age at inclusion, 
weight, height, haemoglobin level and weighted doses of darbepoetin alfa were compared by the Wilcoxon-MannWhitney test, a nonparametric test for independent samples.

\section{Results}

Patient disposition

Among the 54 chronic renal failure paediatric patients enrolled at 12 sites from January 2003 to April 2004, 15 were discarded during the study due to kidney transplantation $(n=14)$ and adverse event (one patient with abdominal pain). The final analysis included 39 patients $(n=10$ in the "naive group", and $n=29$ in the "switched group"). Original diseases were renal hypoplasia-dysplasia with or without uropathy in eight, hereditary disease in nine, glomerulonephritis in ten, haemolytic uraemic syndrome in five, systemic disease in two, interstitial nephritis in one and unknown in four. At baseline, 22 patients received intravenous (i.v.) injections of darbepoetin and 17 patients received subcutaneous (s.c.) injections of darbepoetin. At M6, 25 patients received i.v. injections and 14 received s.c. injections.

\section{Demographics and baseline characteristics}

The groups were comparable for gender and age, while weight and height were lower in the switched group (Table 1). No patients in the naive group underwent dialysis. By contrast, 23 patients $(79.3 \%)$ in the switched group received dialysis (mainly haemodialysis, Table 1). This dialysis status could affect the results.

As expected, the $\mathrm{Hb}$ levels and iron status at baseline differed between the two groups. Mean $\mathrm{Hb}$ level was
$9.5 \pm 2.4 \mathrm{~g} / \mathrm{dl}$ in the naive patients, while switched patients were stabilised at $11.1 \pm 1.2 \mathrm{~g} / \mathrm{dl}$ of $\mathrm{Hb}$, due to their previous treatment.

\section{Dosage of darbepoetin}

When M3 was compared with baseline, the $\mathrm{Hb}$ levels increased in 34 patients $(87 \%)$, showing a mean increase of $1.8 \mathrm{~g} / \mathrm{dl}(+17 \%)$. The doses of darbepoetin subsequently decreased from $0.73 \mu \mathrm{g} / \mathrm{kg}$ per week to $0.68 \mu \mathrm{g} / \mathrm{kg}$ per week $(-7 \%)$. When M6 was compared with baseline (Table 2), the $\mathrm{Hb}$ levels increased in 29 patients $(74 \%)$, reaching a mean increase of $0.8 \mathrm{~g} / \mathrm{dl}(+8.4 \%)$, despite a dose adjustment at $0.63 \mu \mathrm{g} / \mathrm{kg}$ per week at M6.

The naive and switched groups displayed different behaviours: in the naive patients, the mean levels of $\mathrm{Hb}$ increased by $3.2 \mathrm{~g} / \mathrm{dl}$ up to $\mathrm{M} 3$, then decrease by $1 \mathrm{~g} / \mathrm{dl}$ between $\mathrm{M} 3$ and M6, while darbepoetin doses were stable during this period (Fig. 1a). Thus, the levels of $\mathrm{Hb}$ had increased to $11.7 \pm 1.2 \mathrm{~g} /$ dl $(+2.1 \mathrm{~g} / \mathrm{dl}$ or $+22 \%)$ by M6, compared with those at baseline (Table 2) with a final dose of $0.34 \pm 0.25 \mu \mathrm{g} / \mathrm{kg}$ per week (Fig. 1a), representing a 36\% reduction compared to the initial doses. In the "switched" patients the mean $\mathrm{Hb}$ had increased to $12.3 \pm 1.5 \mathrm{~g} / \mathrm{dl}$ by $\mathrm{M} 3$ and had stabilised at $11.5 \pm$ $1.7 \mathrm{~g} / \mathrm{dl}(+0.4 \mathrm{~g} / \mathrm{dl}$ or $+4 \%)$ by M6, while the final dose of $0.73( \pm 0.50) \mu \mathrm{g} / \mathrm{kg}$ per week was quite similar to the initial doses (Fig. 1b). Finally, in the period M3-M6, darbepoetin doses were higher in the switched patients than in the naive patients for similar $\mathrm{Hb}$ levels (Table 2).

\section{Evolution of DA doses and $\mathrm{Hb}$}

Among the 39 patients, 26 patients $(66.7 \%)$ reached a target $\mathrm{Hb}>11 \mathrm{~g} / \mathrm{dl}$. In these 26 patients who maintained the target
Table 1 Demographic and baseline characteristics $(n=39)$ (Naive not previously treated with r-HuEPO, Switched previously treated with r-HuEPO, T-sat transferrin saturation

\footnotetext{
${ }^{\text {a }}$ Statistical tests: WilcoxonMann-Whitney exact test for continuous variables and Fisher's exact test for categorical variables ${ }^{\mathrm{b}}$ Values expressed as mean \pm standard deviation ${ }^{c}$ Number of patients/number of examined patients $(\%)$
}

\begin{tabular}{lllll}
\hline Characteristics & Naïve $(n=10)$ & Switched $(n=29)$ & Total $(n=39)$ & $P^{\mathrm{a}}$ \\
\hline Gender $($ male/female $)$ & $4 / 6$ & $15 / 14$ & $19 / 20$ & 0.716 \\
Age $(\text { years })^{\mathrm{b}}$ & $15.7 \pm 2.0$ & $15.1 \pm 2.2$ & $15.2 \pm 2.1$ & 0.412 \\
Weight $(\mathrm{kg})^{\mathrm{b}}$ & $49.5 \pm 14.7$ & $38.7 \pm 7.8$ & $41.4 \pm 10.9$ & 0.030 \\
Height $(\mathrm{cm})$ & $152.0 \pm 12.6$ & $148.0 \pm 12.0$ & $149.0 \pm 12.1$ & 0.281 \\
Dialysis, $n(\%)^{\mathrm{b}}$ & $0(0.0)$ & $23(79.3)$ & $23(58.9)$ & $<0.001$ \\
Haemodialysis & $0(0.0)$ & $17(73.9)$ & $17(73.9)$ & \\
Peritoneal dialysis & $0(0.0)$ & $6(26.1)$ & $6(26.1)$ & \\
Haemoglobin, $n$ & 9 & 29 & 38 & \\
Mean $\pm \mathrm{SD}(\mathrm{g} / \mathrm{dl})$ & $9.5 \pm 2.4$ & $11.1 \pm 1.2$ & $10.7 \pm 1.7$ & 0.140 \\
Hb $<11 \mathrm{~g} / \mathrm{dl}{ }^{\mathrm{c}}$ & $6(66.7)$ & $14(48.3)$ & $20(52.6)$ & 0.454 \\
Ferritin, $n$ & 9 & 25 & 34 & \\
Mean $\pm \mathrm{SD}(\mu \mathrm{g} / \mathrm{dl})$ & $202.8 \pm 190.2$ & $391.2 \pm 339.6$ & $341.3 \pm 315.8$ & 0.154 \\
$<100(\mu \mathrm{g} / \mathrm{L}){ }^{\mathrm{c}}$ & $5(55.6)$ & $6(24.0)$ & $11(32.4)$ & 0.111 \\
T-sat, $n$ & 5 & 22 & 27 & \\
Mean $\pm \mathrm{SD}(\mu \mathrm{g} / \mathrm{dl})$ & $35.7 \pm 12.9$ & $32.5 \pm 18.3$ & $33.1 \pm 17.2$ & 0.492 \\
$<20 \%, n(\%)^{\mathrm{c}}$ & $0(0.0)$ & $4(18.2)$ & $4(14.8)$ & 0.561 \\
\hline
\end{tabular}


Table $2 \mathrm{Hb}$ levels, doses of darbepoetin alfa and iron status according to the previous treatment (Naive not previously treated with r-HuEPO,

Switched previously treated with r-HuEPO)

${ }^{\mathrm{a}} n=9$ for $\mathrm{Hb}$ levels at baseline

${ }^{\mathrm{b}}$ Statistical tests: WilcoxonMann-Whitney exact test for continuous variables and Fisher's exact test for categorical variables

${ }^{\mathrm{c}}$ Change values were calculated comparing the baseline to M6

${ }^{d}$ Number of patients/number of examined patients $(\%)$

\begin{tabular}{|c|c|c|c|c|}
\hline Parameter & Naïve $(n=10)^{\mathrm{a}}$ & Switched $(n=29)$ & Total $(n=39)$ & $P^{\mathrm{b}}$ \\
\hline \multicolumn{5}{|l|}{$\mathrm{Hb}, \mathrm{g} / \mathrm{dl}$} \\
\hline \multicolumn{5}{|l|}{ Baseline } \\
\hline Mean \pm SD & $9.5 \pm 2.4$ & $11.1 \pm 1.2$ & $10.7 \pm 1.7$ & \multirow[t]{2}{*}{0.140} \\
\hline $95 \% \mathrm{CI}$ & {$[7.7 ; 11.4]$} & {$[10.6 ; 11.5]$} & {$[10.2 ; 11.3]$} & \\
\hline \multicolumn{5}{|l|}{ M6 } \\
\hline Mean \pm SD & $11.7 \pm 1.2$ & $11.5 \pm 1.7$ & $11.6 \pm 1.6$ & \multirow[t]{2}{*}{0.822} \\
\hline $95 \% \mathrm{CI}$ & {$[10.9 ; 12.6]$} & {$[10.8 ; 12.2]$} & {$[11.0 ; 12.1]$} & \\
\hline \multicolumn{5}{|l|}{ Change $^{c}$} \\
\hline Mean \pm SD & $2.1 \pm 2.6$ & $0.4 \pm 2.1$ & $0.8 \pm 2.3$ & \multirow[t]{2}{*}{0.126} \\
\hline $95 \% \mathrm{CI}$ & {$[0.1 ; 4.1]$} & {$[-0.4 ; 1.2]$} & {$[0.1 ; 1.6]$} & \\
\hline \multicolumn{5}{|c|}{ Doses, $\mu \mathrm{g} / \mathrm{kg}$ per week } \\
\hline \multicolumn{5}{|l|}{ Baseline } \\
\hline Mean \pm SD & $0.53 \pm 0.23$ & $0.80 \pm 0.55$ & $0.73 \pm 0.50$ & \multirow[t]{2}{*}{0.159} \\
\hline $95 \% \mathrm{CI}$ & {$[0.35 ; 0.70]$} & {$[0.59 ; 1.01]$} & {$[0.57 ; 0.90]$} & \\
\hline \multicolumn{5}{|l|}{ M6 } \\
\hline Mean \pm SD & $0.34 \pm 0.25$ & $0.73 \pm 0.50$ & $0.63 \pm 0.48$ & \multirow[t]{2}{*}{0.015} \\
\hline $95 \% \mathrm{CI}$ & {$[0.16 ; 0.52]$} & {$[0.54 ; 0.92]$} & {$[0.48 ; 0.79]$} & \\
\hline Change $^{c}$ & $-35.8 \%$ & $-8.8 \%$ & $-13.7 \%$ & \\
\hline \multicolumn{5}{|c|}{ Ferritin $<100 \mu \mathrm{g} / 1$} \\
\hline Baseline & $5 / 9(55.6)^{\mathrm{d}}$ & $6 / 25(24.0)^{\mathrm{d}}$ & $11 / 34(32.4)^{\mathrm{d}}$ & 0.111 \\
\hline M6 & $2 / 9(22.2)^{\mathrm{d}}$ & $3 / 25(12.0)^{\mathrm{d}}$ & $5 / 34(14.7)^{\mathrm{d}}$ & 0.591 \\
\hline \multicolumn{5}{|l|}{ T-sat $<20 \%$} \\
\hline Baseline & $0 / 5(0.0)^{\mathrm{d}}$ & $4 / 22(18.2)^{\mathrm{d}}$ & $4 / 27(14.8)^{\mathrm{d}}$ & 0.561 \\
\hline M6 & $0 / 5(0.0)^{\mathrm{d}}$ & $5 / 21(23.8)^{d}$ & $5 / 26(19.2)^{d}$ & 0.545 \\
\hline
\end{tabular}

$\mathrm{Hb}$ at $\mathrm{M} 6$ ( $\mathrm{Hb} \geq 11 \mathrm{~g} / \mathrm{dl}$ group), the mean $\mathrm{Hb}$ level increased by $1.7 \mathrm{~g} / \mathrm{dl}$, with a concomitant reduction of $24 \%$ in the mean darbepoetin dose (Table 3). Among the $\mathrm{Hb} \geq 11 \mathrm{~g} / \mathrm{dl}$ group ( $n=26), 19$ patients belonged to the switched group and seven to the naive group. By contrast, in the $\mathrm{Hb}<11 \mathrm{~g} /$ $\mathrm{dl}$ group (the 13 remaining patients) the mean $\mathrm{Hb}$ level decreased by $0.89 \mathrm{~g} / \mathrm{dl}$, in spite of an increase of $7 \%$ of the mean darbepoetin doses. Among these 13 patients, a mean $\mathrm{Hb}$ increase of $3.5 \mathrm{~g} / \mathrm{dl}$ was observed in six patients, but this increase of $\mathrm{Hb}$ level failed to reach the target because the initial $\mathrm{Hb}$ levels were very low. Among the seven patients with erythropoietin resistance during the 6-month follow-up, one had a primary infection of tuberculosis, one underwent orthopaedic surgery, two stopped the treatment for 1 month, one had an inappropriate dosage of darbepoetin and two had an unexplained decrease in $\mathrm{Hb}$ level between M5 and M6).

Iron supplementation, ferritin and T-sat levels over the study

The proportion of patients with ferritin $<100 \mu \mathrm{g} / \mathrm{l}$ decreased from baseline to M6, from $55.6 \%$ to $22.2 \%$ and from $24 \%$ to $12 \%$ for naive patients and switched patients, respectively (Table 2). Many patients had changes in their mode of administration, either i.v. or oral supplementation during the 6 months of the study. At baseline, 14 patients received oral supplementation (seven in the naive group), and 17 received i.v. supplementation (one naive). No transferrin values $<20 \%$ were seen for naive patients over the followup, while the proportion of switched patients having transferrin values $<20 \%$ increased by $5.6 \%$ (Table 2 ). Interestingly, the proportion of patients with ferritin $<100 \mu \mathrm{g} / \mathrm{l}$ at baseline was higher in the group who had not achieve the target $\mathrm{Hb}>11 \mathrm{~g} / \mathrm{dl}$ (Table 3).

Dosing intervals

At baseline, 92.1\% patients - all of the naive group and $89.7 \%$ of the switched group - received darbepoetin once a week, and $7.9 \%$ received it every other week. At M6, $76.9 \%$ patients (30\% naive and $93 \%$ switched), were still receiving darbepoetin once a week, $15.4 \%$ patients $(40 \%$ naïve and $6.9 \%$ switched) received darbepoetin every other week, and $7.7 \%$ patients $(30 \%$ naive patients and $0 \%$ switched) had one dose per month.

\section{Safety and tolerance}

Two patients reported adverse events: vascular access thrombosis in one $(\mathrm{Hb}=11.1 \mathrm{~g} / \mathrm{dl})$, and abdominal pain in a second, leading to their withdrawal from the study, although no relation with treatment was demonstrated in these two patients. One patient needed a transfusion at baseline $(\mathrm{Hb} 5.3 \mathrm{~g} / \mathrm{dl})$ and his inclusion is questionable. 


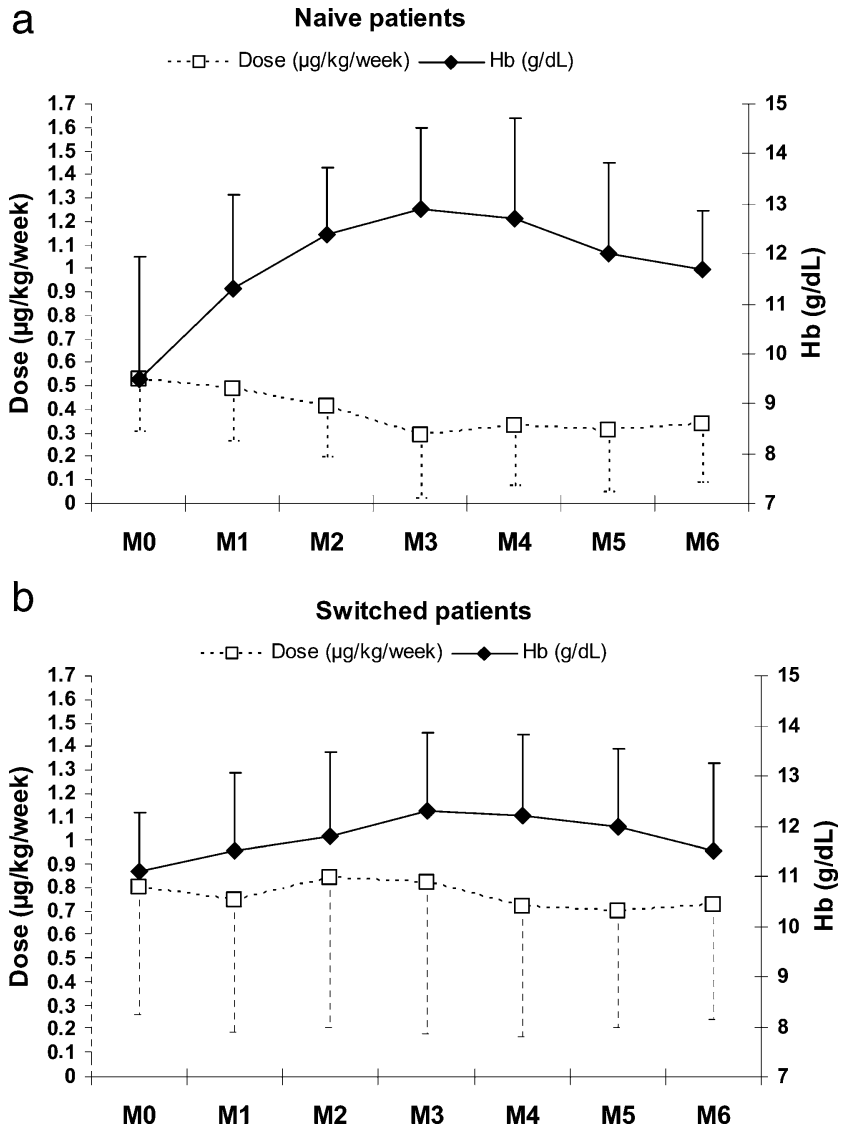

Fig. 1 Evolution of haemoglobin $(\mathrm{Hb})$ concentration $(\mathrm{g} / \mathrm{dl})$ and darbepoetin alfa dose $(\mu \mathrm{g} / \mathrm{kg}$ per week) over time according to previous treatment. Naive patients, $n=10$ (a) and switched patients, $n=29$ (b). (Mean and SD)

\section{Discussion}

The objective of this study was to determine the mean dose of darbepoetin necessary to control anaemia in CRF children aged 11 years to 18 years. The patients were followed-up for 6 months under usual routine practice. Two populations of patients were defined: "naive" patients (not previously treated with r-HuEPO) and "switched" patients (previously treated with $\mathrm{r}-\mathrm{HuEPO}$ and switched to darbepoetin). The two populations differed by: (1) their baseline $\mathrm{Hb}$ levels, (2) their darbepoetin doses at inclusion, (3) dialysis status (none on dialysis in the naive group, $73.9 \%$ on dialysis - mainly haemodialysis - in the switched group). Our series showed that (1) darbepoetin efficacy was demonstrated in either naive patients or in switched patients, where $\mathrm{Hb}$ levels increased following 3 months of darbepoetin therapy, (2) darbepoetin doses were lowered by $36 \%$ to stabilise the haemoglobin level within the expected target in the naive patients and (3) darbepoetin dosage was twice as high in switched patients than in naive patients to
Table $3 \mathrm{Hb}$ levels, darbepoetin doses and iron status according to the target $\mathrm{Hb}$ at M6 (Naive not previously treated with $\mathrm{r}-\mathrm{HuEPO}$, Switched previously treated with $\mathrm{r}-\mathrm{HuEPO})$

\begin{tabular}{|c|c|c|c|}
\hline Parameter & $\begin{array}{l}\mathrm{Hb} \geq 11 \mathrm{~g} / \mathrm{dl} \\
(n=26)\end{array}$ & $\begin{array}{l}\mathrm{Hb}<11 \mathrm{~g} / \mathrm{dl} \\
(n=13)\end{array}$ & $P^{\mathrm{a}}$ \\
\hline \multicolumn{4}{|l|}{$\mathrm{Hb}, \mathrm{g} / \mathrm{dl}$} \\
\hline \multicolumn{4}{|l|}{ Baseline } \\
\hline Mean \pm SD & $10.8 \pm 1.5$ & $10.6 \pm 2.0$ & \multirow[t]{2}{*}{0.853} \\
\hline $95 \% \mathrm{CI}$ & {$[10.2 ; 11.4]$} & {$[9.3 ; 11.8]$} & \\
\hline \multicolumn{4}{|l|}{ M6 } \\
\hline Mean \pm SD & $12.5 \pm 0.9$ & $9.8 \pm 1.0$ & \multirow[t]{2}{*}{$<0.001$} \\
\hline $95 \%$ CI & {$[12.1 ; 12.8]$} & {$[9.2 ; 10.4]$} & \\
\hline \multicolumn{4}{|l|}{ Change $^{\mathrm{b}}$} \\
\hline Mean \pm SD & $1.7 \pm 1.8$ & $-0.8 \pm 2.4$ & \multirow[t]{2}{*}{0.001} \\
\hline $95 \% \mathrm{CI}$ & {$[0.9 ; 2.4]$} & {$[-2.3 ; 0.6]$} & \\
\hline \multicolumn{4}{|c|}{ Doses $(\mu \mathrm{g} / \mathrm{kg}$ per week) } \\
\hline \multicolumn{4}{|l|}{ Baseline } \\
\hline Mean \pm SD & $0.75 \pm 0.48$ & $0.71 \pm 0.54$ & \multirow[t]{2}{*}{0.580} \\
\hline $95 \% \mathrm{CI}$ & {$[0.55 ; 0.95]$} & {$[0.38 ; 1.04]$} & \\
\hline \multicolumn{4}{|l|}{ M6 } \\
\hline Mean \pm SD & $0.57 \pm 0.37$ & $0.76 \pm 0.64$ & \multirow[t]{3}{*}{0.447} \\
\hline $95 \% \mathrm{CI}$ & {$[0.42 ; 0.72]$} & {$[0.37 ; 1.14]$} & \\
\hline Change $^{\mathrm{b}}$ & $-24.0 \%$ & $+7.0 \%$ & \\
\hline \multicolumn{4}{|c|}{ Ferritin $<100 \mu \mathrm{g} / 1$} \\
\hline Baseline & $6 / 23(26.1)^{\mathrm{c}}$ & $5 / 11(45.5)^{\mathrm{c}}$ & 0.434 \\
\hline M6 & $4 / 21(19.1)^{\mathrm{c}}$ & $1 / 13(7.7)^{c}$ & 0.627 \\
\hline \multicolumn{4}{|l|}{ T-sat $<20 \%$} \\
\hline Baseline & $2 / 19(10.5)^{\mathrm{c}}$ & $2 / 8(25.0)^{\mathrm{c}}$ & 0.558 \\
\hline M6 & $2 / 16(12.5)^{\mathrm{c}}$ & $3 / 10(30.0)^{\mathrm{c}}$ & 0.340 \\
\hline
\end{tabular}

${ }^{a}$ Statistical tests: Wilcoxon-Mann-Whitney exact test for continuous variables and Fisher's exact test for categorical variables

${ }^{\mathrm{b}}$ Change values were calculated comparing the baseline to M6

${ }^{\mathrm{c}}$ Number of patients/number of examined patients (\%)

maintain a similar haemoglobin level by 6 months of treatment.

These results extend those of recent publications where darbepoetin was found to be effective in controlling anaemia in seven children on haemodialysis [17] and in a group of 26 children across the spectrum of chronic renal failure to end-stage renal disease [18]. A decrease in the doses, together with less frequent injections, reinforces the interest of treating CRF patients with darbepoetin, owing to a parallel reduction in morbidity and care costs. Previous studies have shown that darbepoetin can effectively maintain haemoglobin concentrations when given at extended dose intervals relative to $\mathrm{r}-\mathrm{HuEPO}$ in dialysis subjects [15, 19-21]. The conversion index of $1 \mu \mathrm{g}$ darbepoetin/200 U r-HuEPO appeared satisfactory in our population, while maintaining stable $\mathrm{Hb}$ concentrations in the switched group.

In the present study, which included children aged 11 years to 18 years, a different behaviour was observed according to the previous treatment status, i.e. between the 
naive and the switched patients. Higher darbepoetin doses were needed in the switched patients to maintain the target $\mathrm{Hb}$ level. This difference was seen from the start (initial darbepoetin doses were proportional to the previous r-HuEPO dose) to the end of the study. Several factors could explain the differences in darbepoetin dose between the groups. Actually, $79 \%$ of patients of the switched group received dialysis, while no dialysis patient was included in the naive group. Thus, the stage of chronic kidney disease was more severe in the former group, with a possibly more reduced residual EPO secretion, more important blood loss and more accumulation of anti-erythropoiesis inhibitors [22]. In progressive renal failure, the rHuEPO dose required to attain target $\mathrm{Hb}$ levels was shown to increase as patients' renal function deteriorated [23]. In addition, none of the naive patients versus $5 / 21$ of switched patients had T-sat $<20 \%$ at M6. An important consideration when one is treating anaemia in CRF patient is iron availability for erythropoiesis [24]. Despite the prescription of iron supplementation, the proportion of children with transferrinsaturation $<20 \%$ appeared more important in the groups of patients having $\mathrm{Hb}<11 \mathrm{~g} / \mathrm{dl}$ by M6. An adequate and continuous correction of the absolute and functional deficiency of iron reserves is necessary during treatment to optimise the darbepoetin efficacy in those patients, as recommended in KDOQI [25].

The tolerance of darbepoetin was excellent. In the present study one patient discontinued the treatment because of abdominal pain possibly related to darbepoetin. No injection pain was spontaneously reported during the patient's follow-up. However, no specific question was included in the protocol.

In summary, darbepoetin alfa is a tool adapted to treat anaemia in children with chronic renal failure aged 11 years to 18 years at extended dosing intervals. Patients previously treated with $\mathrm{r}-\mathrm{HuEPO}$ require higher darbepoetin doses than naive patients do, most likely due to a longer period of chronic renal failure, dialysis status, and reduced level of residual erythropoietin secretion, exacerbated iron loss and accumulation of erythropoiesis inhibitors. The clear decrease in dose and lengthening of the treatment interval in nearly all the naive patients (all pre-dialysis) suggest that in children with chronic renal disease - particularly if they do not yet require dialysis - the administration of darbepoetin alfa every 15 days from the start of the treatment may be a good option, as seems to be demonstrated in recent publications in adults [26].

Acknowledgements This study was supported by a grant from Amgen France to the French Society of Paediatric Nephrology. The authors wish to thank Christophe Pompon and Jean-Christophe Réglier from Amgen France. They are grateful to Mathieu Robain, Sébastien Marque and Gaëlle Chenuc from société 3 ES, for their assistance in compiling the data and for their statistical analysis.

\section{References}

1. Foley RN, Parfrey PS, Harnett JD, Kent GM, Murray DC, Barre PE (1996) The impact of anemia on cardiomyopathy, morbidity, and mortality in end-stage renal disease. Am J Kidney Dis 28:53-61

2. Brandt JR, Avner ED, Hickman RO, Watkins SL (1999) Safety and efficacy of erythropoietin in children with chronic renal failure. Pediatr Nephrol 13:143-147

3. Jabs K, Harmon WE (1996) Recombinant human erythropoietin therapy in children on dialysis. Adv Ren Replace Ther 3:24-36

4. McDougall IC, Davies R, Hutton R, Cavill I, Lewis N, Coles G, Williams J (1990) The treatment of renal anemia in CAPD patients with recombinant human erythropoietin. Nephrol Dial Transplant 5:950-955

5. Burke JR (1995) Low dose subcutaneous recombinant erythropoietin in children with chronic renal failure. Pediatr Nephrol 9:558-561

6. Walter T, De Andraca T, Chadud P, Perales C (1989) Iron deficient anemia: adverse effects on infant psychomotor development. Pediatrics 84:7-17

7. Weiss LG, Clyne N, Divino Fihlho J, Frisenette-Fich C, Kurkus J, Svensson B (2000) The efficacy of once weekly compared with two or three times weekly subcutaneous epoetin $\beta$ : results from a randomized controlled multicentre trial. Nephrol Dial Transplant 15:2014-2019

8. Locatelli F, Baldamus CA, Villa G, Ganea A, Martin de Francisco AL (2002) Once-weekly compared with three-times-weekly subcutaneous epoetin $\beta$ : results from a randomized, multicenter, therapeutic-equivalence study. Am J Kidney Dis 40:119-125

9. McDougall IC (2002) Once-weekly erythropoietic therapy: is there a difference between the available preparations? Nephrol Dial Transplant 17:2047-2051

10. Brandt JR, Avner ED, Hickman RO, Watkins SL (1999) Safety and efficacy of erythropoietin in children with chronic renal failure. Pediatr Nephrol 13:143-147

11. Chavers BM, Roberts TL, Herzog CA, Collins AJ, St Peter WL (2004) Prevalence of anemia in erythropoietin-treated pediatric as compared to adult chronic dialysis patients. Kidney Int 65:266-273

12. Egrie JC, Browne JK (2001) Development and characterization of novel erythropoiesis stimulating protein (NESP). Nephrol Dial Transplant 16:3-13

13. Egrie JC, Dwyer E, Browne JK, Hitz A, Lykos MA (2003) Darbepoetin alfa has a longer circulating half-life and greater in vivo potency than recombinant human erythropoietin. Exp Hematol 31:290-299

14. Lerner G, Kale AS, Warady BA, Jabs K, Bunchman TE, Heatherington A, Olson K, Messer-Mann L, Maroni BJ (2002) Pharmacokinetics of darbepoetin alfa in pediatric patients with chronic kidney disease. Pediatr Nephrol 17:933-937

15. Brunkhost R, Bommer J, Braun J, Haag-Weber M, Gill C, Wagner J, Wagener $T$ (2004) Darbepoetin alfa effectively maintains haemoglobin concentrations at extended dose intervals relative to intravenous or subcutaneous recombinant human erythropoietin in dialysis patients. Nephrol Dial Transplant 19:1224-1230

16. Bristoyiannis G, Germanos N, Grekas D, Hatzidimitrou C, Iatrou C, Memmos D, Moutafis S, Papachristoforou K, Papadoniou A, Pappas M, Sakellariou GA, Siamopoulos KC, Sombolos K, Stamatelou K, Stathakis CP, Stavgiannoudakis G, Stratigis S, Syrganis C, Tsakiris D, Valis D, Vlahojannis JG, Vlassopoulos D (2005) Unit dosing of DA for the treatment of anemia in patients with end-stage renal disease being switched from recombinant human erythropoietin: results of a phase IIIb, 27-week, multicenter, open-label study in Greek patients. Curr Ther Res Clin Exp $66: 195-210$ 
17. De Palo T, Giordano M, Palumbo F, Bellantuono R, Messina G, Colella V, Caringella AD (2004) Clinical experience with darbepoetin alfa (NESP) in children undergoing hemodialysis. Pediatr Nephrol 19:337-340

18. Geary DF, Keating LE, Vigneux A, Stephens D, Hébert D, Harvey EA (2005) Darbepoetin alfa (Aranesp) in children with chronic renal failure. Kidney Int 68:1759-1765

19. Warady BA, Arar MY, Lerner G, Nakanishi AM, Stehman-Breen C (2006) Darbepoetin alfa for the treatment of anemia in pediatric patients with chronic kidney disease. Pediatr Nephrol 21:11441152

20. Vanrenterghem Y, Barany P, Mann JF, Kerr PG, Wilson J, Baker N, Gray SJ, European/Australian NESP 970200 Study Group (2002) Randomized trial of darbepoetin alfa for treatment of renal anemia at a reduced dose frequency compared with $\mathrm{rHuEPO}$ in dialysis patients. Kidney Int 62:2167-2175

21. Locatelli F, Canaud B, Giacardy F, Martin-Malo A, Baker N, Wilson J (2003) Treatment of anemia in dialysis patients with unit dosing of darbepoetin alfa at a reduced dose frequency relative to recombinant human erythropoietin (rHuEPO). Nephrol Dial Transplant 18:362-369

22. Macdougall IC (2001) Role of uremic toxins in exacerbating anemia in renal failure. Kidney Int Suppl 8:S67-S72

23. Ifudu O, Cohen LS, Mayers JD, Joseph A, Delano BG, Friedman EA (2001) Residual renal function modulates response to erythropoietin in chronic renal insufficiency. Dial Transplant 30:344-354

24. Frankenfield DL, Neu AM, Warady BA, Fivush BA, Johnson CA, Brem AS (2003) Anemia in pediatric hemodialysis patients: results from the 2001 ESRD Clinical performance measures project. Kidney Int 64:1120-1124

25. KDOQI National Kidney Foundation (2006) III Clinical Practice recommendations for anaemia in chronic kidney disease in children. Am J Kidney Dis 47:S86-S108

26. Toto RD, Pichette V, Navarro J, Brenner R, Carroll W, Liu W, Roger S (2004) Darbepoetin alfa effectively treats anemia in patients with chronic kidney disease with de novo every-otherweek administration. Am J Nephrol 24:453-460 